\title{
Morphological Adjustment of Kahang River Consequent to Construction of Kahang Dam
}

\author{
Muhammad Nda ${ }^{1,2}$, Mohd Shalahuddin Adnan ${ }^{1}$, Mohd Azlan Bin Mohd Yusoff ${ }^{1}$, \\ Gideon Jiya Shabako ${ }^{2}$, Yakubu Musa ${ }^{2}$
}

1 Universiti Tun Hussein Onn Malaysia

Parit Raja, Batu Pahat, Johor, 86400, Malaysia

${ }^{2}$ The Federal Polytechnic, Bida

KM 1.5, Doko Road, Bida, Niger State, Nigeria

DOI: $10.22178 /$ pos.62-4

LCC Subject Category: TD1-1066

Received 25.08.2020

Accepted 28.09.2020

Published online 30.09 .2020

Corresponding Author:

Muhammad Nda

muhdnda@gmail.com

(c) 2020 The Authors. This article

is licensed under a Creative Commons

Attribution 4.0 License @) (1)

\begin{abstract}
In a tropical country like Malaysia, the availability of research works to monitor channel changes as a response to situating a dam over an observation period may help to establish new management strategies. These investigations will constitute a vital approach in assessing the changes to channel morphology downstream due to the presence of a dam and its operations. In the present study, the effects of Kahang Dam on Kahang River morphology, in particular, the downstream section was investigated and analyzed between January 2017 to January 2018. The rainfall pattern of the study period, the flow regime concerning the period, and geomorphological channel adjustments were carried out during the field surveys over a 400 meters reach. Different responses were leading to high flow and low flow regimes during periods with and without any interference due to dam operations. Similarly, the river channel was characterized by adjustments and realignments, causing modifications to the river morphology. Changes in cross-sectional area and local incision were also noticed as a direct response to sediment deficit and bank erosion process.
\end{abstract}

Keywords: Kahang River; kahang Dam effects; Downstream morphological adjustment.

\section{INTRODUCTION}

Generally, river flows are closely related to channel flood control and navigation [1]. The river course evolution has distinctive features and is influenced by multiple factors, including upstream flow, channel boundary, hydrological patterns, and downstream water level [2]. After the introduction of a dam for water impoundment purposes, it is essential to adjust to the changes as regards the hydrological conditions and other factors of the downstream section [3]. The impact of dams on downstream river morphology has already been discussed in a variety of studies offering a list of river morphological reactions, with [4] presenting a detailed literature review on the effect of dams on downstream river morphology. These studies do not differentiate rivers based on their bed material and controlled flow patterns, and for this reason, they cannot be used to determine the morphological response of a particular river. Dams cause a combination of reduction of flow and accumulation of sediment. Initially, rivers seem to be more resilient to decreased flow and show signs of sediment deposition, but as time passes, sediment trapping in the upstream reservoir reverses this tendency and the riverbank and bed begin to erode, resulting in channel incision [5]. If the incision progresses, the main river channel is isolated from the flood plains because high flows are no longer able to flood them [6]. Most of the sand bed rivers have been observed to react to dams in this way.

Channel morphology, consisting of dimensions of width, depth, and slope, which are a function of discharge regime and sediment contribution. Any adjustment in discharge and sediment 
concentration below the dam is expected to alter the existing balance or equilibrium, thereby causing channel form adjustment [7]. Sediment concentration is a primary factor associated with the downstream impact of the dams. Sediment concentration is considered to be vital in ensuring a balance between natural and anthropogenic factors by changing channel form [8]. Water flowing from dams downstream significantly decreases the suspended sediment concentration, and this sediment deficiency is projected to result in an increased rate of channel bed and bank erosion [9]. Nevertheless, the relationship between river damming and the commonly assumed dominance of downstream erosion is not consistent. It has been found to differ with time following the closure of the dam, for instance, a study done on the Red River in Vietnam by [10] and the distance from the dam as documented by [11] in the Mekong River, suggest that suspended sediment concentration was found to recover as the distance from the dam increased.

Several kinds of research have been carried out focusing on the consequences of introducing a dam on a river as regards the downstream sediment deficit and flow reduction with little work done on the aspect of the river morphological change, for example, findings arising from a review paper by [12] on sediment load change in the Yangtze River. Similarly, studies by $[13,14]$ presented the effects of damming as regards suspended sediment trapping and flow reduction for the Yangtze River and Mekong River, respectively. Besides, authors [15] carried out a study downstream Kahang River on bedload sediment concentration variabilities due to Kahang Dam. Therefore, further studies are needed to examine the response of river morphology downstream dam reaches considering many factors such as sediment transport, flow regime, hydrological pattern, channel bed, and bank erosion.

The present study aims to explore the morphological adjustments at the downstream reaches of Kahang Dam by considering the dam operations, flow regime, and rainfall pattern. The findings will provide an insight into how the factors, as mentioned earlier, contribute to changes in Kahang River morphological adjustment. Additionally, the findings can be used to deduce appropriate strategies for protection and management for dam downstream reaches.

\section{MATERIALS AND METHODS}

Malaysia is located near the equator characterized by high solar energy all through the year. The air is mostly moist and commonly covered with clouds all year round. Johor is in the southern region of Peninsular Malaysia and is divided into eight administrative districts. Kluang, where the study area is situated, is a district in the centre of the state of Johor, located on coordinate $2.0301^{\circ} \mathrm{N}, 103.3185^{\circ} \mathrm{E}$. This area received about $2100-2500 \mathrm{~mm}$ of rainfall every year, with an average temperature of $28^{\circ} \mathrm{C}$.

For this study, the cross-section of the river will be divided into elemental strips of equal width using a graduated line, which will be pegged at the two ends of the river cross-section. Changes to river morphology that is caused downstream the river due to dam regulation are measured using crosssection repeated survey technique. Cross-section of the river channel is benchmarked at each end in such a way that it can be identified and resurveyed [16]. Starting from the dam stilling basin, firm wooden pegs of $1.2 \mathrm{~m}$ to $1.5 \mathrm{~m}$ in length were driven into the ground at $25 \mathrm{~m}$ interval. The pegs were mounted at the two sides (right- and lefthand side) of the riverbank until the $400 \mathrm{~m}$ reach. The width is measured across the river channel at $90^{\circ}$ to the channel at about $0.2 \mathrm{~m}$ above the water level. The start and finish point for width measurement is the active river state (not considering the floodplain). The river depth is measured at the midpoint of each benchmark (mounted peg) along the river cross-section using a ranging pole. The change in the area and subsequently total surface area of the river morphology was calculated starting from January 2017 to January 2018 (i.e., January, March, May, July, September, November all in 2017 and January 2018) as represented by Equation 1 and 2 respectively. The measurements were taken once in two months to see the morphological adjustment of the river channel over time.

$$
C A=w d
$$

where $C A=$ cross - sectional area $\left(\mathrm{m}^{2}\right)$;

$w=$ active width of the channel $(m)$;

$d=$ midpoint depth of the channel $(m)$.

$$
R S A=\sum_{i=1}^{n} C A_{i}
$$

where $R S A=$ Total River surface area $\left(\mathrm{m}^{2}\right)$; 


$$
\begin{aligned}
& C A_{i} \\
& =\text { cross } \\
& \text { - sectional area }\left(\mathrm{m}^{2}\right) \text { for each chainage }
\end{aligned}
$$

$$
\text { (i.e.Ch } 25 \text {.......Ch 400) }
$$

Velocity measurement. The flow rate (velocity) measurements were equally taken at the same midpoint were the depth measurements were taken during the cross-sectional survey using the Electric magnetic water current and speed meter. The current meter is an instrument made up of the following; current speed sensor, LCD system, and a post holder. Flow measurement was taken by lowering the current sensor to a depth $0.6 \mathrm{~d}$ below the water, and the corresponding flow rate $(\mathrm{Vm} / \mathrm{s})$ displayed on the LCD system after $30 \mathrm{sec}-$ onds and reading recorded [17]. These measurements were taken at the same time with the river channel cross-sectional surveys once in two months, to give ample time for visible changes.

Precipitation data of the study area were collected using a rain gauge and from the Malaysian Metrological Department (MMD) during the study period. The rain gauge was positioned around the study area, and precipitation data was observed and collected for one-year data (January 2017 January 2018).

\section{RESULTS AND DISCUSSIONS}

The effects of dams on the river morphology are studied because dams tend to retain sediments and induce flow reduction downstream of its host. In the beginning, rivers appear to show elements of sediment deposition, but with time this tendency disappears as most sediments are trapped in the reservoir upstream, and the riverbed starts to respond with channel incision as a result of eroding. Continuous river channel incision will force the main river channel to shrink and disconnected from its floodplains because inundation caused by high flows is no more. This phenomenon is the typical response of most rivers to the dam.

Morphological changes observed between January 2017 to January 2018 was facilitated by reference benchmarks established along the riverbank. Analysis of the repeated river cross-sectional measurement was used in defining the channel boundary changes and calculation of channel total surface area change of the river downstream of the dam and presented in Table 1.

Table 1 - Morphological adjustment of Kahang River based on the change in channel surface area, $\mathrm{m}^{2}$

\begin{tabular}{|l|r|r|r|r|r|r|r|}
\hline Chainage (m) & January 2017 & March & May & July & September & November & January 2018 \\
\hline 25 & 54.5 & 53 & 52.5 & 45 & 242.5 & 247.5 & 244.25 \\
\hline 50 & 121.5 & 117 & 115 & 164 & 260 & 270 & 263.5 \\
\hline 75 & 369 & 367.5 & 352.5 & 445.5 & 780 & 795 & 785.25 \\
\hline 100 & 551 & 532 & 510 & 930 & 1070 & 1070 & 1053 \\
\hline 125 & 647.5 & 637.5 & 612.5 & 1212.5 & 1325 & 1337.5 & 1321.25 \\
\hline 150 & 885 & 810 & 750 & 885 & 1260 & 1297.5 & 1278 \\
\hline 175 & 1146.25 & 1050 & 980 & 1050 & 1417.5 & 1456 & 1433.25 \\
\hline 200 & 1398 & 1300 & 1220 & 1360 & 1340 & 1320 & 1294 \\
\hline 225 & 1300.5 & 1237.5 & 1215 & 1395 & 1462.5 & 1496.25 & 1467 \\
\hline 250 & 1162.5 & 1150 & 1100 & 1325 & 2050 & 2087.5 & 2055 \\
\hline 275 & 1339.25 & 1210 & 1100 & 1512.5 & 1677.5 & 1727 & 1691.25 \\
\hline 300 & 1359 & 1350 & 1290 & 1680 & 2220 & 2265 & 2226 \\
\hline 325 & 1365 & 1365 & 1300 & 1787.5 & 2405 & 2470 & 2405 \\
\hline 350 & 1522.5 & 1505 & 1435 & 1785 & 1785 & 1925 & 1855 \\
\hline 375 & 1492.5 & 1462.5 & 1425 & 1987.5 & 2662.5 & 2625 & 2550 \\
\hline 400 & 1688 & 1600 & 1560 & 2132 & 2880 & 3000 & 2920 \\
\hline Total surface area $\left(\mathrm{m}^{2}\right)$ & 16402 & 15747 & 15017.5 & 19696.5 & 24837.5 & 25389.25 & 24841.75 \\
\hline
\end{tabular}

The river channel downstream of the dam has shown variable rates of velocity and change relationships considering the measured area over the period (Figure 1 and Figure 2, respectively). The period between January to May 2017, the river channel area was seen to decrease steadily from one month to the other, and May 2017 represents the smallest surface area $(15017.5 \mathrm{~m} 2)$ throughout the measurement period. The effect of the dam caused the decrease during this period as 
most of the water meant to flow downstream naturally is retained in the reservoir. In contrast to measurements taken between January to May 2017, the river channel surface area shows a gradual increase starting July 2017 with an area of $19696.5 \mathrm{~m}^{2}$. The increment was due to an increase in water discharge from the dam (additional outlet open), there was a further increase in the surface area of the river channel between September and November having $24837.5 \mathrm{~m}^{2}$ and $25389.25 \mathrm{~m}^{2}$ respectively as presented in Table 1. However, in January 2018, there was a slight decline in the measured surface area to 24841.75 $\mathrm{m} 2$, even though the flow rate was still high. In the preceding months explicitly starting in September, the dam overflow was left open, letting out a large volume of water at a very high flow rate (Figure 1).

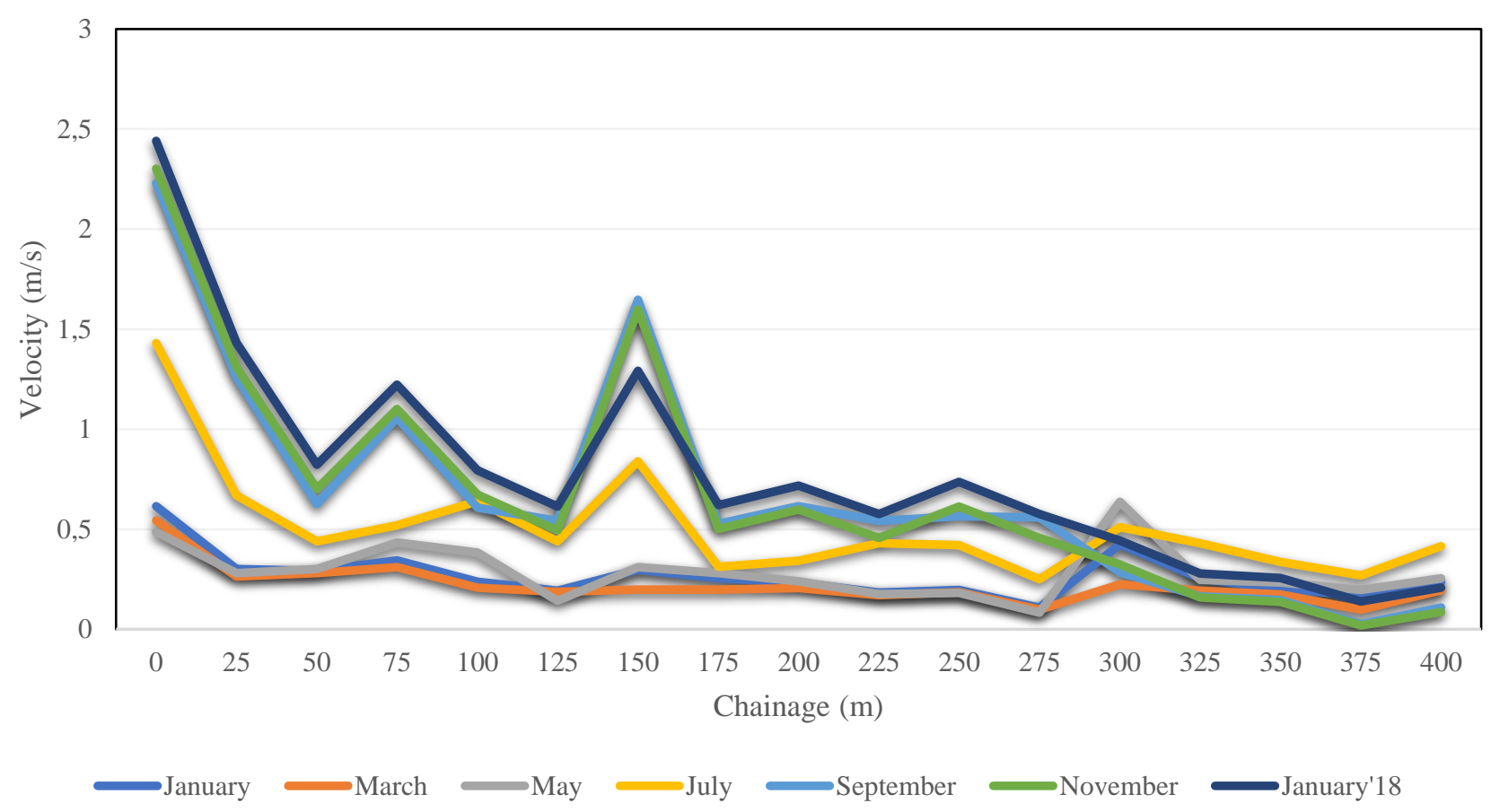

Figure 1 - Flow rate of downstream channel change

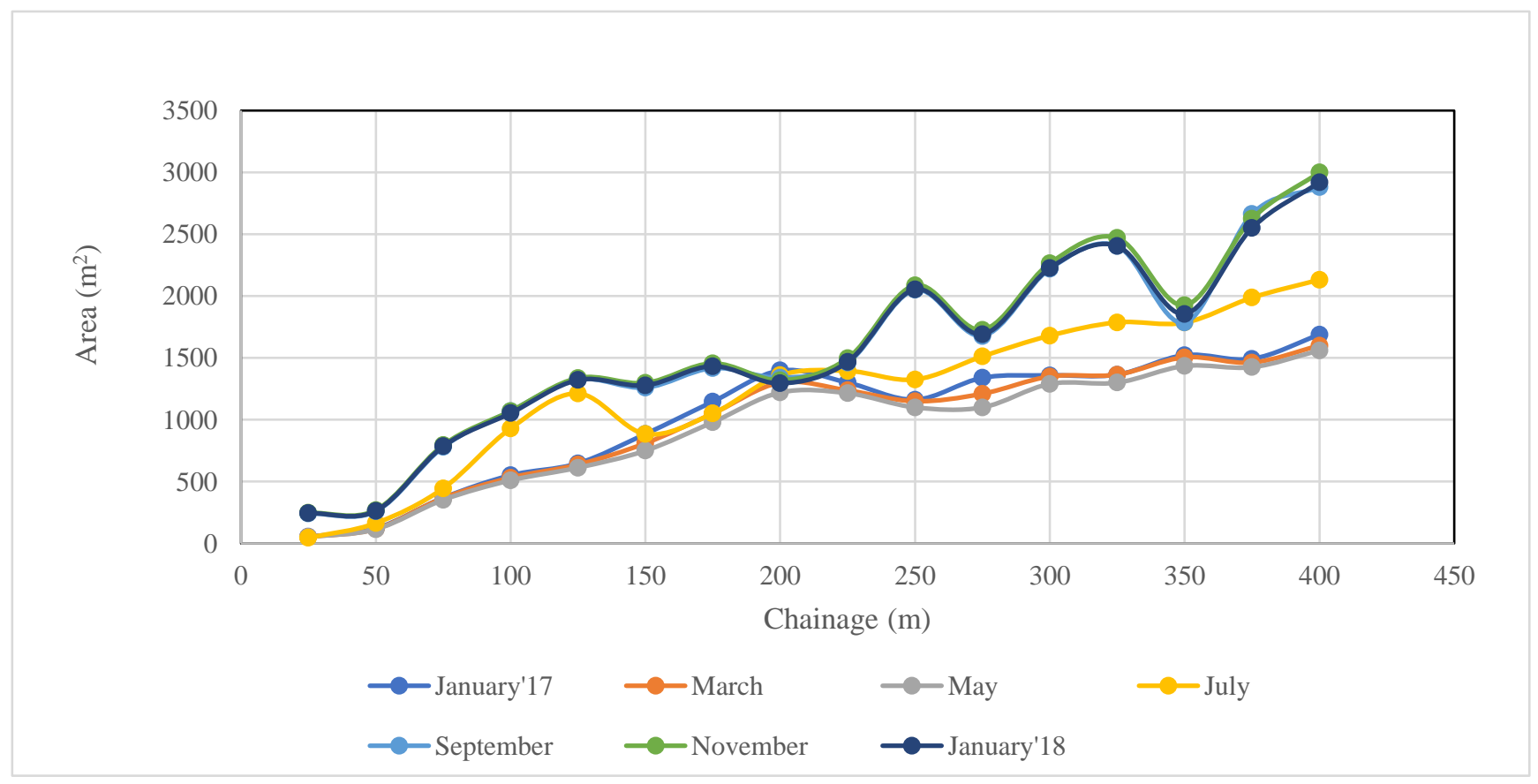

Figure 2 - Downstream channel change during the study period 
The additional water release through the dam overflow downstream was responsible for the vast difference between these two periods (January -May 2017 and July - January 2018). Aside from the dam operation effects, the relatively high rainfall depth during the period (between July 2017 to January 2018) also contributed to the changes measured (Figure 3).

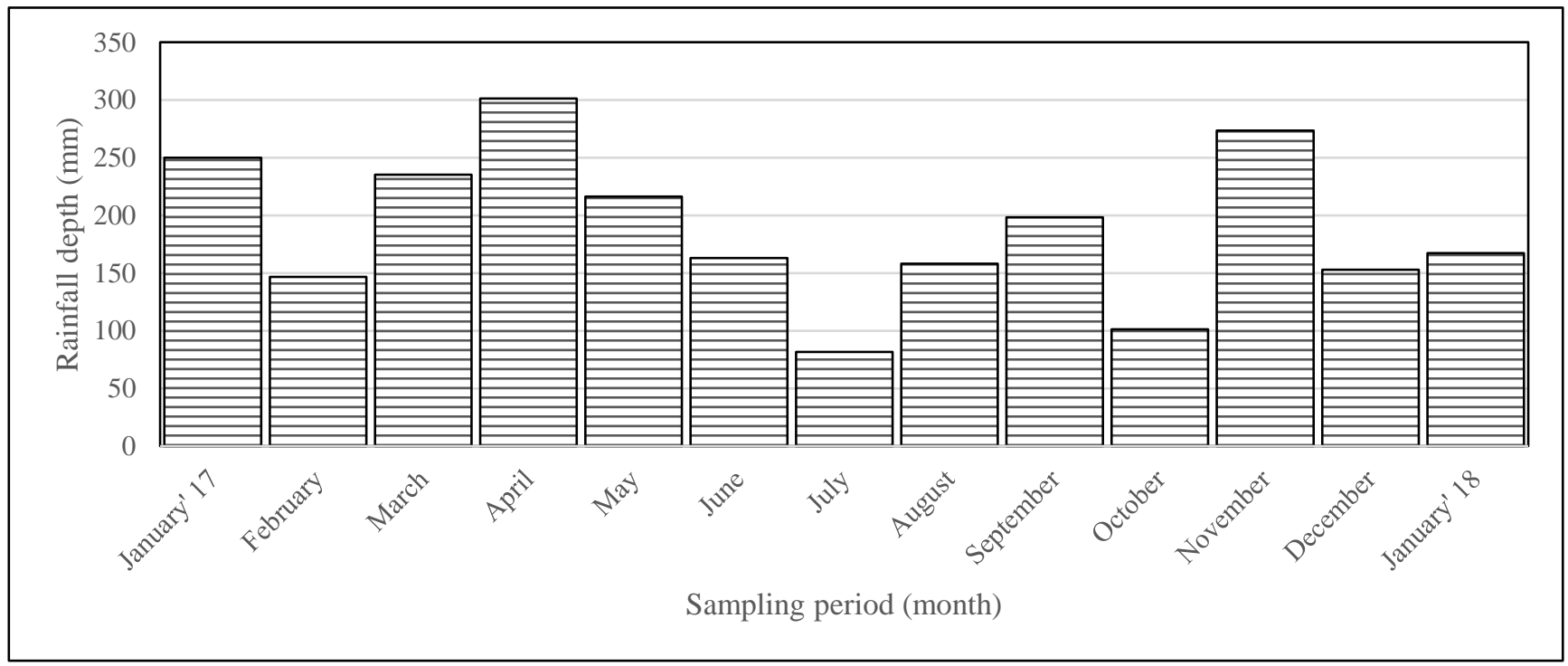

Figure 3 - Rainfall depth during the study period

The changes in Kahang river morphology downstream Kahang dam during the study period may seem not to have a steady incision effect and have been widely reported in similar studies. However, the first few measurements have that semblance area reducing in May to $15017.5 \mathrm{~m}^{2}$ from 16402 $\mathrm{m}^{2}$ in January. But a continuous incision was abridged by the dam operators opening additional water outlet and eventually opening the dam overflow.

\section{CONCLUSIONS}

In conclusion, this study presents the effect of Kahang Dam operations on the downstream reaches of Kahang River. Based on the finding's policymakers and relevant government agencies responsible for the design and operations of dams should be encouraged to take seriously the morphological response of rivers downstream and provide adequate floodplain vegetation, which will ensure riverbanks are protected from erosion. The change in flow regime due to the dam operations causing an alteration to the river morphology has been identified to have impacted adversely on the floodplain vegetation, thereby varying its primary regeneration ability resulting in negative consequences for the immediate local fauna and the aquatic environment.

\section{REFERENCES}

1. Edwards, B. L., Keim, R. F., Johnson, E. L., Hupp, C. R., Marre, S., \& King, S. L. (2016). Geomorphic adjustment to hydrologic modifications along a meandering river: Implications for surface flooding on a floodplain. Geomorphology, 269, 149-159. doi: 10.1016/j.geomorph.2016.06.037

2. Han, J., Zhang, W., Fan, Y., \& Yu, M. (2017). Interacting effects of multiple factors on the morphological evolution of the meandering reaches downstream the Three Gorges Dam. Journal of Geographical Sciences, 27(10), 1268-1278. doi: 10.1007/s11442-017-1434-0

3. Khan, O., Mwelwa-Mutekenya, E., Crosato, A., \& Zhou, Y. (2014). Effects of dam operation on downstream river morphology: the case of the middle Zambezi River. Proceedings of the Institution of Civil Engineers - Water Management, 167(10), 585-600. doi:

10.1680/wama.13.00122 
4. Childs, M. (2010). Literature survey: the impacts of dams on river channel geomorphology. Retrieved from https://issuu.com/aalandscapeurbanism/docs/aalu2014_the_riparian_land-shaping_/45

5. Ronco, P., Fasolato, G., Nones, M., \& Di Silvio, G. (2010). Morphological effects of damming on lower Zambezi River. Geomorphology, 115(1-2), 43-55. doi: 10.1016/j.geomorph.2009.09.029

6. Li, Y., Sun, Z., Liu, Y., \& Deng, J. (2009). Channel Degradation Downstream from the Three Gorges Project and Its Impacts on Flood Level. Journal of Hydraulic Engineering, 135, 718-728.

7. Sanyal, J. (2017). Predicting possible effects of dams on downstream river bed changes of a Himalayan river with morphodynamic modelling. Quaternary International, 453, 48-62. doi: 10.1016/j.quaint.2017.03.063

8. Rădoane, M., Obreja, F., Cristea, I., \& Mihailă, D. (2013). Changes in the channel-bed level of the eastern Carpathian rivers: Climatic vs. human control over the last 50years. Geomorphology, 193, 91-111. doi: 10.1016/j.geomorph.2013.04.008

9. Surian, N., \& Cisotto, A. (2007). Channel adjustments, bedload transport and sediment sources in a gravel-bed river, Brenta River, Italy. Earth Surface Processes and Landforms, 32(11), 1641-1656. doi: 10.1002/esp.1591

10. Lu, X. X., Oeurng, C., Le, T. P. Q., \& Thuy, D. T. (2015). Sediment budget as affected by construction of a sequence of dams in the lower Red River, Viet Nam. Geomorphology, 248, 125-133. doi: 10.1016/j.geomorph.2015.06.044

11. Lu, X. X., \& Siew, R. Y. (2006). Water discharge and sediment flux changes over the past decades in the Lower Mekong River: possible impacts of the Chinese dams. Hydrology and Earth System Sciences, 10(2), 181-195. doi: 10.5194/hess-10-181-2006

12. Dai, S. B., \& Lu, X. X. (2014). Sediment load change in the Yangtze River (Changjiang): A review. Geomorphology, 215, 60-73. doi: 10.1016/j.geomorph.2013.05.027

13. Dai, Z., \& Liu, J. T. (2013). Impacts of large dams on downstream fluvial sedimentation: An example of the Three Gorges Dam (TGD) on the Changjiang (Yangtze River). Journal of Hydrology, 480, 10-18. doi: 10.1016/j.jhydrol.2012.12.003

14. Kondolf, G. M., Rubin, Z. K., \& Minear, J. T. (2014). Dams on the Mekong: Cumulative sediment starvation. Water Resources Research, 50(6), 5158-5169. doi: 10.1002/2013wr014651

15. Adnan, M. S., Nda, M., Mohammad Razi, M. A., Mohd Yusoff, M. A., Rahmat, S. N., Abustan, M. S., \& Ahmad Tajudin, S. A. (2018). Bedload Sediment Concentration of Sungai Kahang Downstream Kahang Dam in Johor. International Journal of Integrated Engineering, 10(2). Retrieved from https://publisher.uthm.edu.my/ojs/index.php/ijie/article/view/2644

16. Schoonover, J. E., Lockaby, B. G., \& Shaw, J. N. (2007). Channel morphology and sediment origin in streams draining the Georgia Piedmont. Journal of Hydrology, 342(1-2), 110-123. doi: 10.1016/j.jhydrol.2007.05.017

17. Nda, M., Jimoh, O. D., \& Adnan, M. S. (2018). Estimation of Sediment Concentration of River Dagga, Chanchaga Basin, Niger State, Nigeria. Lecture Notes in Civil Engineering, 1467-1477. doi: 10.1007/978-981-10-8016-6_106 